\title{
PENGARUH STRATEGI DIRECTED READING THINKING ACTIVITY (DRTA) TERHADAP KETERAMPILAN MEMBACA INTENSIF KELAS III SDN PONDOK MAKMUR KOTA TANGERANG
}

\author{
Eka Putri Haryani ${ }^{1}$, Hamdah Siti Hamsanah Fitriani ${ }^{2}$, Dilla Fadhillah ${ }^{3}$ \\ Universitas Muhammadiyah Tangerang \\ ekaputryharyani@gmail.com ${ }^{1}$ \\ vitrianivit@gmail.com ${ }^{2}$ \\ dillafadhillah89@gmail.com ${ }^{3}$
}

\begin{abstract}
ABSTRAK
Penelitian ini bertujuan untuk mengetahui pengaruh strategi Directed Reading Thinking Activity (DRTA) terhadap keterampilan membaca intensif pada siswa kelas 3 SDN Pondok Makmur Kota Tangerang. Penelitian ini menggunakan pendekatan penelitian kuantitatif. Jenis penelitian ini adalah Quasi Eksperimen dengan bentuk desain statis dua kelompok. Variabel terikat keterampilan membaca intensif dan variabel bebasnya adalah strategi Directed Reading Thinking Activity (DRTA). Subjek penelitian adalah siswa kelas 3 SDN Pondok Makmur Kota Tangerang. Objek penelitian ini adalah pengaruh strategi DRTA terhadap keterampilan membaca intensif. Instrumen yang digunakan dalam penelitian ini adalah tes dan observasi. Setelah data terkumpul dilakukan analisis data. Hasil analisis menunjukkan rata-rata nilai pretest kelas kontrol yaitu 60,63. Rata-rata pretest kelas eksperimen yaitu 61,39. Setelah dilakukan tindakan pada kedua kelas, maka diperoleh rata-rata postest kelas eksperimen yaitu 75,30 dan kelas kontrol 72,30. Hasil perhitungan uji hipotesis pada data postest $\mathrm{f}_{\text {hitung }}=2,809$ pada taraf signifikansi $a=0,05$ memperoleh $t_{\text {tabel }}=1$,997. $t_{\text {hitung }}>t_{\text {tabel }}$ maka $\mathrm{H}_{0}$ ditolak dan $\mathrm{H}_{1}$ diterima. Hal ini membuktikan bahwa penerapan strategi DRTA berpengaruh terhadap keterampilan membaca intensif pada siswa kelas 3 SDN Pondok Makmur Kota Tangerang.
\end{abstract}

Kata kunci : strategi DRTA, keterampilan membaca intensif

\section{A. PENDAHULUAN}

Pendidikan sangat berpengaruh bagi perubahan seseorang, baik individu mupun peserta didik itu sendiri. Sehingga pemerintah mewajibkan pendidikan 9 tahun, yaitu untuk Sekolah Dasar (SD) 6 tahun, dan Sekolah Menengah Pertama (SMP) 3 tahun. Hal ini jelas membuktikan bahwa pendidikan memang hal yang yang sangat penting bagi seseorang. Maka, hal ini sesuai dengan fungsi dan tujuan dalam pendidikan nasional dalam Undang-Undang Nomor 20 Tahun 2003 tentang Sistem Pendidikan Nasional Bab I Pasal 1 yang berbunyi:

"Usaha sadar dan terencana untuk mewujudkan suasana belajar dan proses pembelajaran agar peserta didik secara aktif mengembangkkan potensi dirinya, masyarakat, bangsa, dan negara".

Berdasarkan undang-undang Republik Indonesia Nomor 20 Tahun 2003 di atas, usaha sadar dan terencana yang dimaksudkan dalam pengertian pendidikan tersebut merupakan usaha 
yang dilakukan oleh semua komponen baik orang tua, guru, dan peserta didik. Untuk lebih menyadari bahwa pendidikan sangatlah penting bagi kehidupan kita. Selain itu juga harus bisa mewujudkan suasana belajar yang nyaman dan mengembangkan proses pembelajaran yang aktif untuk mengembangkan potensi yang di miliki oleh masing-masing peserta didik. Sehingga dapat bermanfaat bagi peserta didik untuk dimasa depan. Tidak hanya untuk dirinya sendiri, namun untuk masyarakat, bangsa, dan negara.

Pendidikan di sekolah juga merupakan salah satu wadah untuk mengembangkan potensi peserta didik. Sekolah Dasar adalah jenjang pendidikan paling dasar pada pendidikan formal di Indonesia. Sekolah dasar ditempuh dalam waktu 6 tahun, mulai dari kelas 1 sampai kelas 6. Pelajar sekolah dasar umumnya berusia 6-12 tahun. Pada saat ini kurikulum yang berlaku di Indonesia adalah kurikulum 2013 yang sudah diterapkan oleh pemerintah untuk menggantikan kurikulum 2006 atau sering di sebut dengan KTSP.

Saat ini sudah diterapkan kurikukum 2013 di sejumlah Sekolah Dasar, dalam kurikulum 2013 terdapat mata pelajaran yang digabungkan. Kurikulum 2013 memiliki empat aspek penilaian, yaitu aspek pengetahuan, aspek keterampilan, aspek sikap, dan perilaku. Di dalam kurikulum 2013 salah satu mata pelajaran yang wajib di pelajari adalah Bahasa Indonesia, ada empat keterampilan berbahasa yang harus dimiliki oleh siswa, keterampilan ini antara lain: Mendengarkan, berbicara, membaca, dan menulis. Dari empat keterampilan yang ada, untuk jenjang pendidikan sekolah dasar yang lebih di tekankan bagaimana cara anak membaca.

Berdasarkan data observasi yang telah peneliti lakukan pada tanggal 30 Oktober 2018, bahwa kriteria ketuntasan minimum (KKM) SDN Pondok Makmur, pada mata pelajaran bahasa Indonesia adalah 75. Dengan hasil belajar pembelajaran bahasa Indonesia peserta didik yaitu, 15 siswa atau $45 \%$ peserta didik mendapatkan nilai di bawah rata-rata nilai ketuntasan kriteria minimum (KKM), sedangkan 18 siswa atau 55\% peserta didik mendapatkan nilai di atas nilai kriteria ketuntasan minimum (KKM) yang telah di tentukan oleh sekolah. Dengan jumlah peserta didik kelas kelas III.B berjumlah 33 siswa.

Adapun faktor-faktor yang mempengaruhi hasil belajar Bahasa Indonesia di karenakan oleh beberapa faktor seperti: Guru masih menggunakan metode konvensional, kurangnya minat belajar siswa terhadap mata pelajaran Bahasa Indonesia, sarana dan prasarana sekolah yang kurang memadai sehingga menghambat proses pembelajaran, lingkungan belajar atau suasana kelas yang tidak kondusif, anggapan Bahasa Indonesia adalah pelajaran yang membosankan sehingga membuat timbul rasa malas untuk mempelajari Bahasa Indonesia. 
Pada penelitian ini, peneliti tertarik memilih strategi Directed Reading Thingking Activity (DRTA) sebagai alat untuk meningkatkan keterampilan membaca intensif anak karena strategi Directed Reading Thingking Activity ini cocok diterapkan untuk kegiatan membaca karena tujuan dari strategi ini untuk melatih siswa berkonsentrasi dan berfikir keras untuk memahami isi dalam suatu bacaan.

\section{B. KAJIAN TEORI}

Menurut Brook dalam Tarigan (2015:36) membaca intensif adalah studi saksama, telaah, teliti, dan penanganan terperinci yang dilaksanakan didalam kelas terhadap suatu tugas yang pendek kira-kira dua sampai empat halaman setiap hari. Membaca intensif adalah kegiatan membaca yang dilakukan secara cepat dan tepat dengan sungguh- sungguh untuk memahami isi bacaan yang dibaca. Dalam membaca intensif, yang terpenting ialah pembaca mendapatkan informasi dari bahan bacaan dan dapat memahami isi bacaan secara keseluruhan dengan harapan pembaca dapat mengingatnya dalam waktu yang relatif lama. Sedangkan keterampilan membaca intensif adalah kemampuan seseorang dalam membaca yang dilakukan secara cepat, cermat, dan teliti terhadap teks yang dibaca.

Menurut Sanjaya (2016:126) dalam dunia pendidikan, strategi diartikan sebagai $a$ plan, method, or series of activities designed to achieves a particular educational goal. Strategi pembelajaran dapat diartikan sebagai perencanaan yang berisi tentang rangkaian kegiatan yang didesain untuk mencapai tujuan pendidikan tertentu. Menurut Stauffer dalam Rahim (2018:47) menciptakan kegiatan "Directed Reading Thinking Activity" (DRTA) yang digunakan untuk kemampuan berpikir kritis, yaitu dengan memfokuskan keterlibatan siswa dengan teks, karena siswa memprediksi dan membuktikannya ketika mereka membaca. Sedangkan Menurut Wulandari dalam Taufina (2016:189) strategi Directed Reading Thinking Activity (DRTA) adalah salah satu strategi dalam pembelajaran membaca pemahaman yang diarahkan untuk mencapai tujuan umum. Strategi ini memfokuskan keterlibatan siswa dengan teks, karena siswa memprediksi dan membuktikannya ketika mereka membaca.

Strategi Directed Reading Thinking Activity (DRTA) merupakan suatu cara yang digunakan oleh seorang pengajar untuk mengajak peserta didik dalam membaca dan Berfikir Secara Langsung (MBL) serta memfokuskan keterlibatan siswa dengan memprediksi dan membuktikan teks bacaan ketika mereka membaca. Strategi Directed Reading Thinking Activity (DRTA) juga melatih siswa untuk berkonsentrasi dan berfikir keras guna memahami isi bacaan secara serius. Menurut Farida Rahim (2018:48) dalam meningkatkan keterampilan 
membaca intensif dengan menggunakan strategi Directed Reading Thinking Activity (DRTA) dapat dilakukan berdasarkan langkah-langkah yaitu 1) membuat prediksi berdasarkan petunjuk judul, 2) membuat prediksi dari petunjuk gambar, 3) membaca bahan bacaan, 4) menilai ketepatan prediksi dan menyesuaikan prediksi, 5) guru mengulang kembali prosedur 1 sampai 4.

\section{METODOLOGI PENELITIAN}

Metode penelitian yang akan digunakan peneliti adalah Metode penelitian kuantitatif dengan metode eksperimen. Menurut Sugiyono (2016:107) metode kuantitatif eksperimen yang dapat diartikan sebagai metode penelitian yang digunakan untuk mencari pengaruh perlakuan tertentu terhadap yang lain dalam kondisi yang terkendali (h.107). Jenis penelitian ini adalah true experimental design dengan menggunakan bentuk desain menggunakan bentuk desain pretest posttest control group design. Populasi dalam penelitian ini yaitu seluruh siswa kelas III SD Pondok Makmur Kota Tangerang. Sampel penelitian yaitu siswa kelas III A dan kelas III B yang berjumlah 66 siswa. Teknik pengumpulan data merupakan cara yang digunakan peneliti dalam mengumpulkan data penelitiannya. Dalam melaksanakan kegiatan penelitian eksperimen ini teknik pengumpulan data yang peneliti lakukan yaitu menggunakan tes dan nontes. Tes yang digunakan yaitu pretest dan postest. Tes yang digunakan pada pada penelitian ini mencakup ranah kognitif pada aspek pengetahuan (C3) dan aspek penerapan (C3). Nontes mencakup observasi dan wawancara.

\section{HASIL PENELITIAN DAN PEMBAHASAN}

Berdasarkan penelitian mengenai keterampilan membaca intensif pada siswa kelas III SDN Pondok Makmur Kota Tangerang pada materi keterampilan membaca intensif yang diberikan kepada dua kelas yaitu kelas kontrol yang diajarkan dengan menggunakan model pembelajaran yang konvensional sebanyak 33 siswa dan kelas eksperimen yang diajarkan dengan menggunakan Strategi Directed Reading Thinking Activity sebanyak 33 siswa. Deskripsi data mengenai keterampilan membaca intensif pada siswa kelas III SDN Pondok Makmur Kota Tangerang pada kedua kelas baik kelas kontrol maupun kelas eksperimen sebagai berikut: 
Tabel 4.1 Distribusi Frekuensi Pretest Kelas Kontrol

\begin{tabular}{|c|c|c|c|c|c|}
\hline $\begin{array}{c}\text { Kelas } \\
\text { Interval }\end{array}$ & $\begin{array}{c}\text { Batas } \\
\text { Kelas }\end{array}$ & $\begin{array}{c}\text { Frekuensi } \\
(\mathbf{f})\end{array}$ & $\begin{array}{c}\text { Frekuensi } \\
\text { Kumulatif } \\
(\mathbf{f k})\end{array}$ & $\begin{array}{c}\text { Nilai } \\
\text { Tengah } \\
(\mathbf{x})\end{array}$ & $\begin{array}{c}\text { Frekuensi } \\
\text { Relatif } \\
(\mathbf{f r}) \%\end{array}$ \\
\hline $45-49$ & $44,5-49,5$ & 4 & 4 & 47 & 12,12 \\
\hline $50-54$ & $49,5-54,5$ & 2 & 6 & 52 & 6,06 \\
\hline $55-59$ & $54,5-59,5$ & 5 & 11 & 57 & 15,15 \\
\hline $60-64$ & $69,5-64,5$ & 14 & 25 & 62 & 42,42 \\
\hline $65-69$ & $64,5-69,5$ & 5 & 30 & 67 & 15,15 \\
\hline $70-74$ & $69,5-74,5$ & 2 & 32 & 72 & 6,06 \\
\hline $75-79$ & $74,5-79,5$ & 1 & 33 & 77 & 3,03 \\
\hline \multicolumn{2}{|r|}{ Jumlah } & 33 & 141 & 434 & $100 \%$ \\
\hline
\end{tabular}

Berdasarkan tabel distribusi frekuensi di atas dapat dibuat histogram, poligon dan ogiv yang disajikan pada tabel 4.1 siswa kelas 3 SDN Pondok Makmur.

\section{Gambar 4.1 Histogram dan Poligon pretest kelas kontrol}

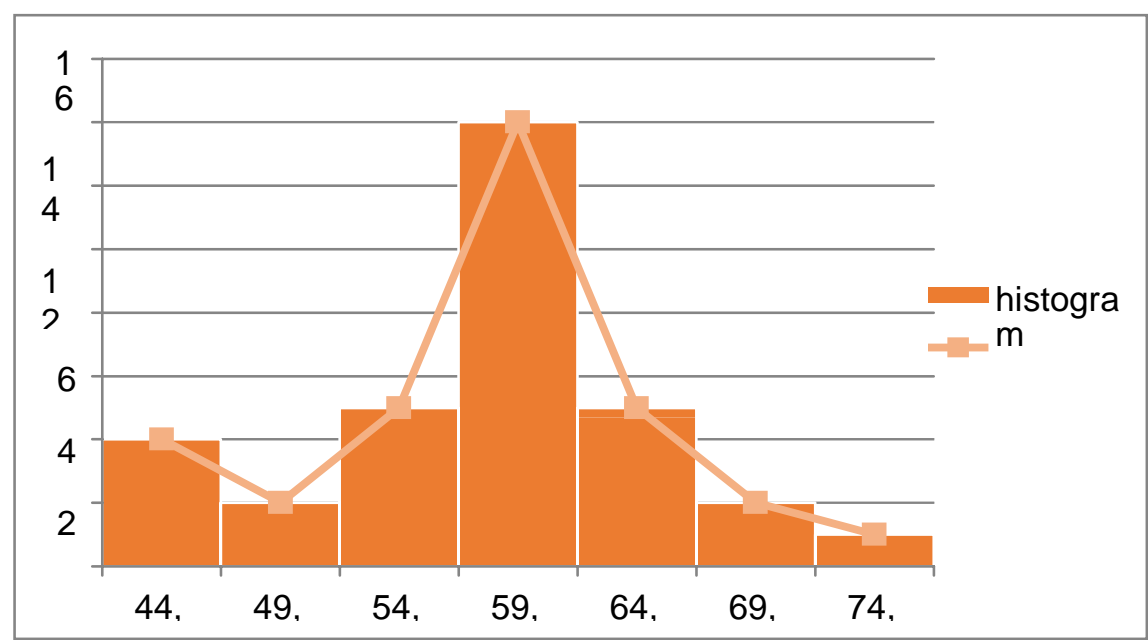

Pada grafik histogram dan poligon pretest kelas kontrol terlihat frekuensi tertinggi pada batas kelas 59,5 yaitu interval 60-64 dengan frekuensi 14. Sedangkan frekuensi terendah pada batas kelas 74,5 yaitu interval 70-75 dengan frekuensi 1. 
Tabel 4.2 Ukuran Pemusatan dan Penyebaran Data Hasil Pretest Kelas Kontrol

\begin{tabular}{|c|c|}
\hline Kelas Kontrol & Nilai \\
\hline Mean & 60,63 \\
\hline Modus & 67 \\
\hline Median & 66,45 \\
\hline Standar Deviasi & 7,31 \\
\hline
\end{tabular}

Tabel 4.3 Distribusi Frekuensi Pretest Kelas Eksperimen

\begin{tabular}{|c|c|c|c|c|c|}
\hline $\begin{array}{c}\text { Kelas } \\
\text { Interval }\end{array}$ & $\begin{array}{c}\text { Batas } \\
\text { Kelas }\end{array}$ & $\begin{array}{c}\text { Frekuensi } \\
(\mathbf{f})\end{array}$ & $\begin{array}{c}\text { Frekuensi } \\
\text { Kumulatif } \\
(\mathbf{f k})\end{array}$ & $\begin{array}{c}\text { Nilai } \\
\text { Tengah } \\
(\mathbf{x})\end{array}$ & $\begin{array}{c}\text { Frekuensi } \\
\text { Relatif } \\
(\mathbf{f r}) \%\end{array}$ \\
\hline $45-49$ & $44,5-49,5$ & 3 & 3 & 47 & 9,09 \\
\hline $50-54$ & $49,5-54,5$ & 4 & 7 & 52 & 12,12 \\
\hline $55-59$ & $54,5-59,5$ & 4 & 11 & 57 & 12,12 \\
\hline $60-64$ & $69,5-64,5$ & 10 & 21 & 62 & 30,30 \\
\hline $65-69$ & $64,5-69,5$ & 8 & 29 & 67 & 24,24 \\
\hline $70-74$ & $69,5-74,5$ & 3 & 32 & 72 & 9,09 \\
\hline $75-79$ & $74,5-79,5$ & 1 & 33 & 77 & 3,03 \\
\hline \multicolumn{2}{|c|}{ Jumlah } & 33 & 136 & 434 & $100 \%$ \\
\hline
\end{tabular}

Berdasarkan tabel distribusi frekuensi di atas dapat dibuat histogram, poligon, dan ogive yang disajikan pada tabel 4.3 siswa kelas III SDN Pondok Makmur.

Gambar 4.2 Histogram dan Poligon Pretest Kelas Eksperimen

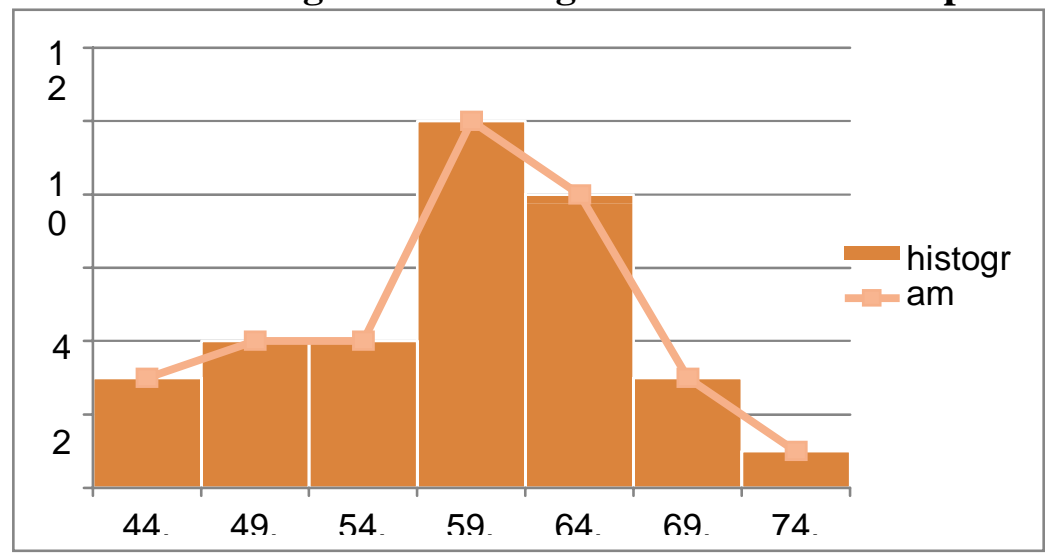


Pada grafik histogram dan poligon pretest kelas eksperimen terlihat frekuensi tertinggi pada batas kelas 59,5 yaitu pada interval 60-64 dengan frekuensi 10. Sedangkan frekuensi terendah pada batas kelas 74,5 yaitu interval 75-79 dengan frekuensi 1.

Tabel 4.4 Ukuran Pemusatan dan Penyebaran Data Hasil Pretest Kelas Eksperimen

\begin{tabular}{|c|c|}
\hline Kelas Interval & Nilai \\
\hline Mean & 61,39 \\
\hline Modus & 68,25 \\
\hline Median & 67,25 \\
\hline Standar deviasi & 7,31 \\
\hline
\end{tabular}

Tabel 4.5 Distribusi Frekuensi Postest Kelas Kontrol

\begin{tabular}{|c|c|c|c|c|c|}
\hline $\begin{array}{c}\text { Kelas } \\
\text { Interval }\end{array}$ & $\begin{array}{c}\text { Batas } \\
\text { Kelas }\end{array}$ & $\begin{array}{c}\text { Frekuensi } \\
\text { (f) }\end{array}$ & $\begin{array}{c}\text { Frekuensi } \\
\text { Kumulatif } \\
\text { (fk) }\end{array}$ & $\begin{array}{c}\text { Nilai } \\
\text { Tengah (x) }\end{array}$ & $\begin{array}{c}\text { Frekuensi } \\
\text { Relatif } \\
\text { (fr) } \%\end{array}$ \\
\hline $55-59$ & $54,5-59,5$ & 2 & 2 & 57 & 6,06 \\
\hline $60-64$ & $59,5-64,5$ & 4 & 6 & 62 & 12,12 \\
\hline $65-69$ & $64,5-68,5$ & 3 & 9 & 67 & 9,09 \\
\hline $70-74$ & $69,5-74,5$ & 9 & 18 & 72 & 15,15 \\
\hline $75-79$ & $74,5-79,5$ & 12 & 30 & 77 & 48,48 \\
\hline $80-84$ & $79,5-84,5$ & 2 & 32 & 82 & 6,06 \\
\hline $85-89$ & $84,5-89,5$ & 1 & 33 & 87 & 3,03 \\
\hline \multicolumn{7}{|c|}{ Jumlah } & 33 & 130 & 504 & 100 \\
\hline
\end{tabular}

Berdasarkan tabel distribusi frekuensi di atas dapat dibuat histogram, poligon dan ogive yang disajikan pada tabel 4.5 siswa kelas III SDN Pondok Makmur. 


\section{Gambar 4.3 Histogram dan Poligon Postest Kelas Kontrol}

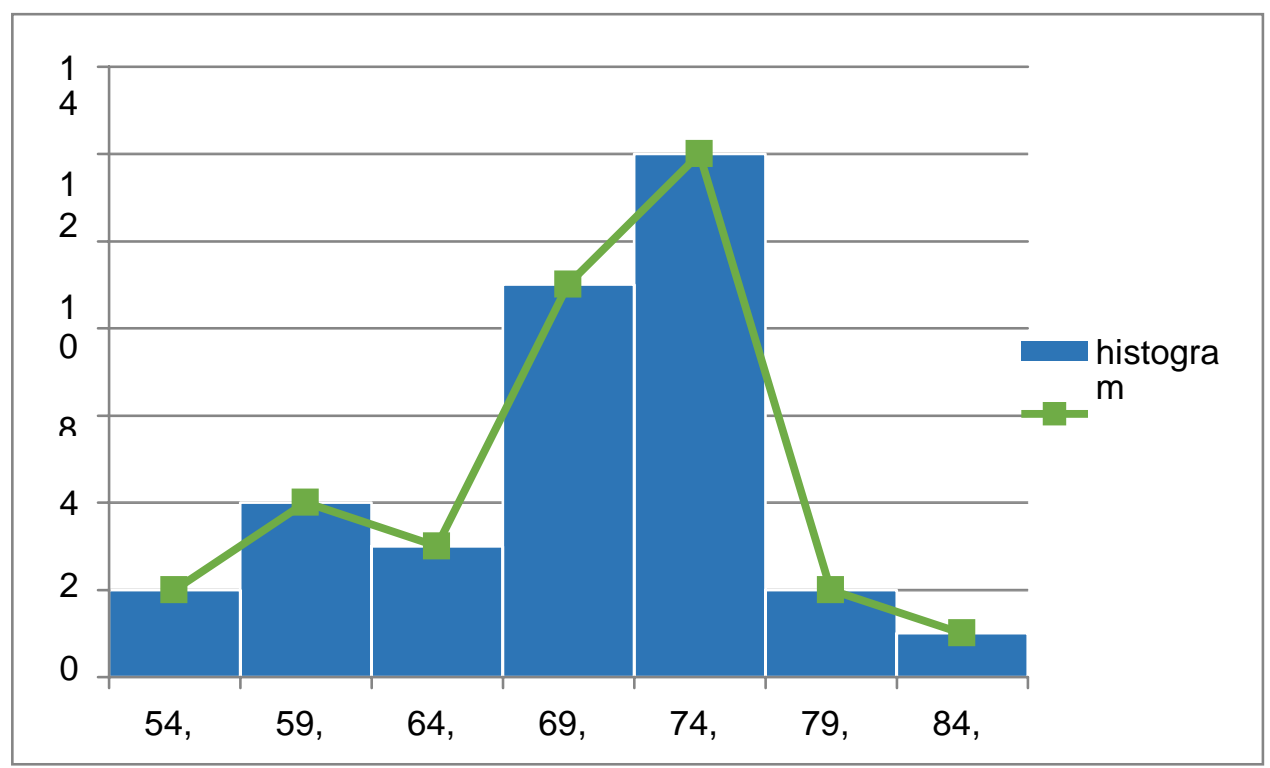

Pada grafik histogram dan poligon postest kelas kontrol terlihat frekuensi tertinggi terdapat pada batas kelas 74,5 yaitu interval 75-79 dengan frekuensi 12. Sedangkan frekuensi terendah pada batas kelas 84,5 yaitu interval 85-89 dengan frekuensi 1.

Tabel 4.6 Ukuran Pemusatan Dan Penyebaran Data Hasil Postest Kelas Kontrol

\begin{tabular}{|c|c|}
\hline Kelas Interval & Nilai \\
\hline Mean & 72,30 \\
\hline Modus & 80,65 \\
\hline Median & 78,65 \\
\hline Standar Deviasi & 7,17 \\
\hline
\end{tabular}

Tabel 4.7 Distribusi Frekuensi Postest Kelas Eksperimen

\begin{tabular}{|c|c|c|c|c|c|}
\hline $\begin{array}{c}\text { Kelas } \\
\text { Interval }\end{array}$ & $\begin{array}{c}\text { Batas } \\
\text { Kelas }\end{array}$ & $\begin{array}{c}\text { Frekuensi } \\
\text { (f) }\end{array}$ & $\begin{array}{c}\text { Frekuensi } \\
\text { Kumulatif } \\
\text { (fk) }\end{array}$ & $\begin{array}{c}\text { Nilai } \\
\text { Tengah (x) }\end{array}$ & $\begin{array}{c}\text { Frekuensi } \\
\text { Relatif } \\
\text { (fr) } \%\end{array}$ \\
\hline $60-64$ & $59,5-64,5$ & 2 & 2 & 62 & 6,06 \\
\hline $65-69$ & $64,5-69,5$ & 3 & 5 & 67 & 9,09 \\
\hline $70-74$ & $69,5-74,5$ & 3 & 8 & 72 & 9,09 \\
\hline $75-79$ & $74,5-79,5$ & 15 & 23 & 77 & 45,45 \\
\hline $80-84$ & $79,5-84,5$ & 5 & 28 & 82 & 15,15 \\
\hline
\end{tabular}




\begin{tabular}{|c|c|c|c|c|c|}
\hline $85-89$ & $84,5-89,5$ & 3 & 31 & 87 & 9,09 \\
\hline $90-94$ & $89,5-94,5$ & 2 & 33 & 92 & 6,06 \\
\hline \multicolumn{2}{|c|}{ Jumlah } & 33 & 130 & 539 & 100 \\
\hline
\end{tabular}

Berdasarkan tabel distribusi frekuensi di atas dapat dibuat histogram, poligon dan ogive yang disajikan pada tabel 4.7 siswa kelas III SDN Pondok Makmur.

Gambar 4.4 Histogram dan Poligon Postest Kelas Eksperimen

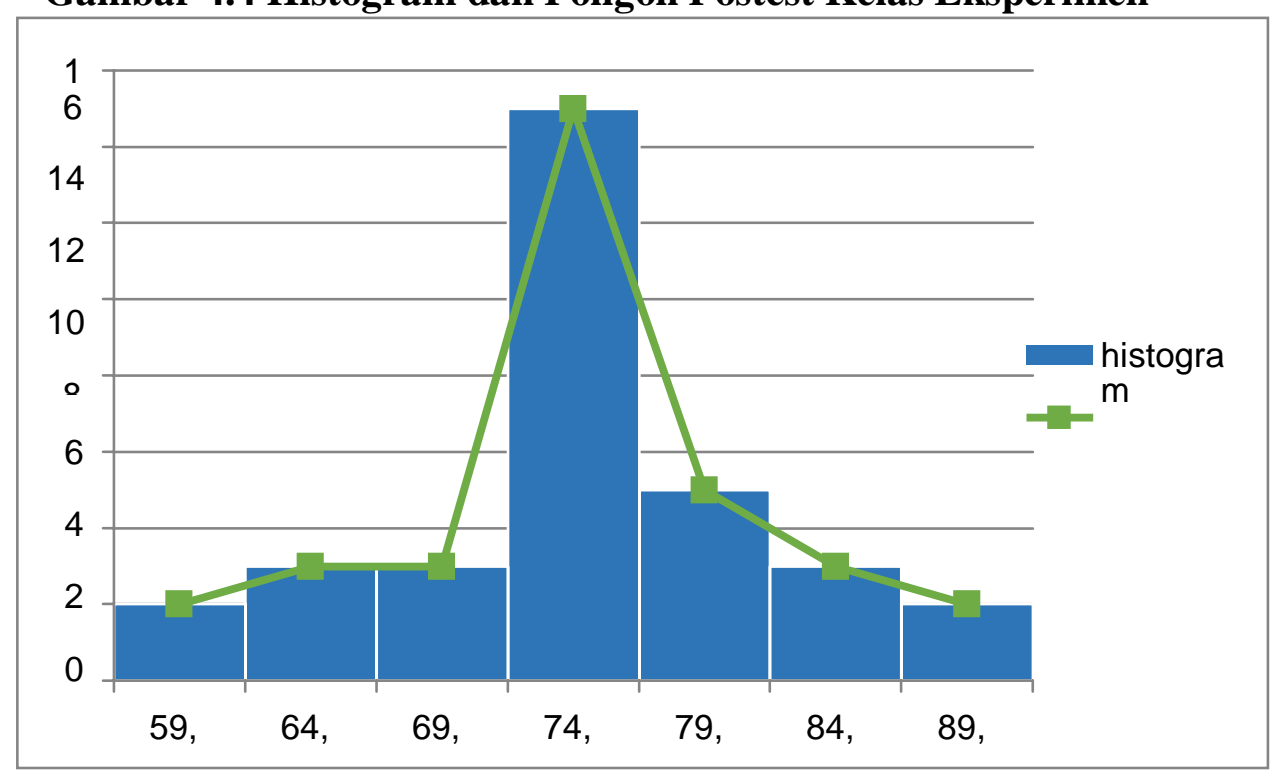

Pada grafik histogram dan poligon postest kelas eksperimen terlihat frekuensi terlihat frekuensi tertinggi terdapat pada batas kelas 74,5 yaitu interval 75-79 dengan frekuensi 15 . Sedangkan frekuensi terendah pada batas kelas 59,5 dan 89,5 yaitu interval 60-64 dan 90-94 dengan masing-masing frekuensi 2.

Tabel 4.8 Ukuran Pemusatan dan Penyebaran Data Hasil Postest Kelas Eksperimen

\begin{tabular}{|c|c|}
\hline Kelas Interval & Nilai \\
\hline Mean & 75,30 \\
\hline Modus & 82,2 \\
\hline Median & 81,3 \\
\hline Standar Deviasi & 7,28 \\
\hline
\end{tabular}




\section{Tabel 4.9 Hasil Perhitungan Uji Normalitas Chi Kuadrat Pretest}

\begin{tabular}{|c|c|l|l|l|}
\hline No & Data & Nilai & Nilai & Keterangan \\
& & $x^{2}$ hitu & $x^{2}$ tabel & \\
\hline 1. & $\begin{array}{c}\text { Nilai Pretest } \\
\text { Kelas Kontrol }\end{array}$ & 9,466 & 12,591 & $\begin{array}{l}\text { Data sampel } \\
\text { berasal dari } \\
\text { populasi } \\
\text { yang } \\
\text { berdistribusi } \\
\text { normal }\end{array}$ \\
\hline & $\begin{array}{c}\text { Kilai Pretes } \\
\text { Eksperimen }\end{array}$ & 7,153 & 12,591 & \\
\hline
\end{tabular}

Tabel 4.10 Hasil Perhitungan Uji Normalitas Chi Kuadrat Postest

\begin{tabular}{|c|c|c|c|c|}
\hline No & Data & $\begin{array}{l}\text { Nilai } \\
x^{2} h i t \\
\text { ung }\end{array}$ & $\begin{array}{c}\text { Nilai } \\
x^{2} \text { tabel }\end{array}$ & Keterangan \\
\hline 1. & $\begin{array}{l}\text { Nilai Pretest } \\
\text { Kelas Kontrol }\end{array}$ & 3,489 & 12,591 & \multirow{2}{*}{$\begin{array}{l}\text { Data sampel } \\
\text { berasal dari } \\
\text { populasi yang } \\
\text { berdistribusi } \\
\text { normal }\end{array}$} \\
\hline 2. & $\begin{array}{c}\text { Nilai Pretes } \\
\text { Kelas } \\
\text { Eksperimen }\end{array}$ & $\begin{array}{c}11,09 \\
7\end{array}$ & 12,591 & \\
\hline
\end{tabular}

Pengujian hipotesis dilakukan dengan menggunakan rumus uji-t, karena sampel berasal dari populasi yang homogen dan berdistribusi normal maka untuk melakukan uji-t menggunakan rumus the pooled variance model t-test. Kriteria uji hipotesis jika $t_{\text {hitung }}<t_{\text {tabel }}$ maka $\mathrm{H}_{\text {diterima, dan }} t_{\text {hitung }}>t_{\text {tabel }}$ maka $\mathrm{H} 1$ diterima. 
Tabel 4.11 Hasil uji-t

\begin{tabular}{|c|c|c|c|}
\hline Data & $\begin{array}{c}\text { Nilai } \\
\text { thitung }_{\text {hitung }}\end{array}$ & $\begin{array}{l}\text { Nilai } \\
t_{\text {tabel }}\end{array}$ & Kesimpulan \\
\hline Pretest & 0,410 & 1,997 & $\begin{array}{l}\mathrm{T}_{\text {hitung }}<\mathrm{t}_{\text {tabel }} \mathrm{H}_{\mathrm{o}} \text { diterima, } \mathrm{H}_{1} \\
\text { ditolak yang artinya tidak terdapat } \\
\text { pengaruh terhadap keterampilan } \\
\text { membaca } \\
\text { intensif antara siswa kelas kontrol } \\
\text { dan siswa kelas eksperimen pada } \\
\text { siswa kelas III SDN Pondok } \\
\text { Makmur dengan signifikansi } \alpha= \\
0,05 \text {. }\end{array}$ \\
\hline Postest & 2,809 & 1,997 & $\begin{array}{l}\text { Thitung > ttabel Ho ditolak, H1 } \\
\text { diterima yang artinya terdapat } \\
\text { pengaruh keterampilan membaca } \\
\text { intensif antara siswa yang } \\
\text { mendapat pembelajaran } \\
\text { menggunakan strategi Directed } \\
\text { Reading Thinking Activity (DRTA) } \\
\text { dengan siswa yang mendapat } \\
\text { pembelajaran hanya } \\
\text { menggunakan } \\
\text { konvensional pada siswa kelas III } \\
\text { SDN Pondok Makmur dengan } \\
\text { signifikansi } \\
\alpha=0,05 \text {. }\end{array}$ \\
\hline
\end{tabular}

Berdasarkan data yang diperoleh, hasil pretest penelitian dengan menggunakan uji-t diketahui bahwa $\mathrm{t}_{\text {hitung }}=0,410<\mathrm{t}_{\text {tabel }} 1,997$ maka $\mathrm{H}_{0}$ diterima. Hal ini menunjukkan bahwa tidak terdapat perbedaan keterampilan membaca intensif antara siswa kelas kontrol dan kelas eksperimen. Hasil postest penelitian dengan menggunakan uji-t diketahui bahwa $t_{\text {hitung }}=2,809$ 
$>$ dari $\mathrm{t}_{\text {tabel }}=1,997$ maka $\mathrm{H}_{0}$ ditolak. Hal ini membuktikan bahwa terdapat pengaruh penggunaan strategi Directed Reading Thinking Activity (DRTA) terhadap keterampilan membaca intensif kelas III SDN Pondok Makmur Kota Tangerang.

\section{E. KESIMPULAN}

Berdasarkan hasil penelitian dan analisis data, maka dapat disimpulkan bahwa penerapan strategi DRTA berpengaruh terhadap keterampilan membaca intensif pada siswa kelas III SDN Pondok Makmur Kota Tangerang. Berdasarkan hasil postest diperoleh bahwa rata-rata keterampilan membaca intensif pada siswa dengan menggunakan strategi DRTA (kelas eksperimen) lebih tinggi dibanding rata-rata keterampilan membaca intensif pada siswa yang diajarkan dengan menggunakan model pembelajaran konvensional (kelas kontrol). Rata- rata nilai pretest yang diperoleh kelas eksperimen yaitu 61,39. Rata-rata pretest kelas kontrol yaitu 60,63. Setelah dilakukan tindakan pada kedua kelas, maka diperoleh rata-rata postest kelas eksperimen yaitu 75,30 dan kelas kontrol 72,30. Hasil perhitungan uji hipotesis pada data postest $\mathrm{f}_{\text {hitung }}=2,809$ pada taraf signifikansi $\mathrm{a}=0,05$ memperoleh $\mathrm{t}_{\text {tabel }}=1,997 . \mathrm{t}_{\text {hitung }}>\mathrm{t}_{\text {tabel }}$ maka $\mathrm{H}_{0}$ ditolak dan $\mathrm{H}_{1}$ diterima. Hal ini membuktikan bahwa penerapan strategi DRTA berpengaruh terhadap keterampilan membaca intensif pada siswa kelas III SDN Pondok Makmur Kota Tangerang.

\section{F. DAFTAR PUSTAKA}

Rahim, Farida. 2018. Pengajaran Membaca Di Sekolah Dasar. Jakarta: Bumi Aksara.

Sanjaya, Wina. 2016. Strategi Pembelajaran Berorientasi Standar Proses Pendidikan. Jakarta: Prenada Media Grup.

Sugiyono, Dr. 2016. Metode Penelitian Kuantitatif, Kualitatif, dan RnD. Bandung: CV. Alfabeta.

Tarigan, Henry Guntur. 2015. Membaca Sebagai Suatu Keterampilan Berbahasa. Bandung: Angkasa

Angkasa. Taufina. 2016. Mozaik Keterampilan Bahasa di Sekolah Dasar. Bandung: Angkasa. 